\title{
The effects of additional black carbon on the albedo of Arctic sea ice: variation with sea ice type and snow cover
}

\author{
A. A. Marks and M. D. King \\ Department of Earth Sciences, Royal Holloway University of London, Egham, Surrey, TW20 0EX, UK \\ Correspondence to: M. D. King (m.king@es.rhul.ac.uk)
}

Received: 31 January 2013 - Published in The Cryosphere Discuss.: 6 March 2013

Revised: 24 June 2013 - Accepted: 27 June 2013 - Published: 30 July 2013

\begin{abstract}
The response of the albedo of bare sea ice and snow-covered sea ice to the addition of black carbon is calculated. Visible light absorption and light-scattering crosssections are derived for a typical first-year and multi-year sea ice with both "dry" and "wet" snow types. The cross-sections are derived using data from a 1970s field study that recorded both reflectivity and light penetration in Arctic sea ice and snow overlying sea ice. The variation of absorption crosssection over the visible wavelengths suggests black carbon is the dominating light-absorbing impurity. The response of first-year and multi-year sea ice albedo to increasing black carbon, from 1 to $1024 \mathrm{ng} \mathrm{g}^{-1}$, in a top $5 \mathrm{~cm}$ layer of a $155 \mathrm{~cm}$-thick sea ice was calculated using a radiative-transfer model. The albedo of the first-year sea ice is more sensitive to additional loadings of black carbon than the multi-year sea ice. An addition of $8 \mathrm{ng} \mathrm{g}^{-1}$ of black carbon causes a decrease to $98.7 \%$ of the original albedo for first-year sea ice compared to a decrease to $99.7 \%$ for the albedo of multiyear sea ice, at a wavelength of $500 \mathrm{~nm}$. The albedo of sea ice is surprisingly unresponsive to additional black carbon up to $100 \mathrm{ng} \mathrm{g}^{-1}$. Snow layers on sea ice may mitigate the effects of black carbon in sea ice. Wet and dry snow layers of $0.5,1,2,5$ and $10 \mathrm{~cm}$ depth were added onto the sea ice surface. The albedo of the snow surface was calculated whilst the black carbon in the underlying sea ice was increased. A layer of snow $0.5 \mathrm{~cm}$ thick greatly diminishes the effect of black carbon in sea ice on the surface albedo. The albedo of a $2-5 \mathrm{~cm}$ snow layer (less than the $e$-folding depth of snow) is still influenced by the underlying sea ice, but the effect of additional black carbon in the sea ice is masked.
\end{abstract}

\section{Introduction}

Changes in the surface albedo of sea ice have a crucial role in determining the magnitude of modern climate change (Curry et al., 1995; Barry, 1996; Perovich et al., 2002; Brandt et al., 2005; Gardner and Sharp, 2010; Perovich and Polashenski, 2012) and can be caused by the addition of black carbon to sea ice (Ledley and Thompson, 1986; Light et al., 1998; Jacobson, 2001; Grenfell et al., 2002). Black carbon has a large light absorption cross-section over shortwave (UV and visible) wavelengths (e.g. Mitchell, 1957; Jacobson, 2001; Hansen and Nazarenko, 2004; Highwood and Kinnersley, 2006; Ramanathan and Carmichael, 2008) and is potentially the second-greatest contributor, by means of direct radiative forcing, to anthropogenic global warming after carbon dioxide (Jacobson, 2001; Ramanathan and Carmichael, 2008). The deposition of black carbon from the atmosphere and incorporation into sea ice causes a decrease in the albedo of sea ice through increased absorption of downwelling solar radiation - potentially resulting in increased melting of sea ice. A loss of sea ice owing to melting causes a drastic decrease in planetary albedo as the large surface albedo of the sea ice is replaced with the small surface albedo of the ocean.

Black carbon is likely to be found in small quantities throughout sea ice due to direct entrainment from seawater (Suman et al., 1997; Dittmar, 2008) and from sediment inclusions where sea ice forms over shallow ocean shelves (Masiello, 1998; Middelburg et al., 1999). Black carbon may also be concentrated in a layer at the sea ice surface due to atmospheric deposition and subsequent surface melting of snow. 
The effects of black carbon in snow have been widely researched (e.g. Chýlek et al., 1983; Warren, 1984; Warren and Wiscombe, 1985; Clarke and Noone, 1985; Warren and Clarke, 1990; Hansen and Nazarenko, 2004; Flanner et al., 2007; Doherty et al., 2010; Reay et al., 2012). Black carbon may reduce the albedo of snow and have a positive climatic radiative forcing, with Clarke and Noone (1985) showing black carbon in snow could reduce albedo by $1-3 \%$. The 2007 IPCC report quantified the possible positive forcing as $0.1 \pm 0.1 \mathrm{~W} \mathrm{~m}^{-2}$ for the time period 1750-2005 (Solomon et al., 2007).

Research into black carbon in sea ice is much less extensive (Ledley and Thompson, 1986; Light et al., 1998; Grenfell et al., 2002; Jacobson, 2004) although research into the optical properties of sea ice is more significant (Grenfell and Maykut, 1977; Perovich et al., 1998, 2002; Perovich, 2003, 2006; Light et al., 2008). Grenfell et al. (2002) demonstrated an increase in summer ablation rate occurs if soot is concentrated near the sea ice surface using a multi-layer four-stream radiative-transfer model to investigate the effect of varying mass ratios and vertical distribution of soot on albedo of the sea ice surface, between the wavelengths of $350-2750 \mathrm{~nm}$. Jacobson (2004) demonstrates that $25 \mathrm{ngg}^{-1}$ of black carbon can reduce surface albedo of sea ice at a wavelength of $550 \mathrm{~nm}$ to $97.9 \%$ of the original value. Using a onedimensional radiative-transfer model Jacobson (2004) investigated the effect of black carbon on albedo and emissivity of snow and sea ice using black carbon concentrations in sea ice of $0-500 \mathrm{ng} \mathrm{g}^{-1}$ and a wavelength range from 200 to $1000 \mathrm{~nm}$. Light et al. (1998) show $150 \mathrm{ngg}^{-1}$ of soot included within sea ice can lead to a decrease in albedo to $70 \%$ of the original value. Light et al. (1998) investigated effects of sediment particles in sea ice on the albedo of sea ice, at wavelengths from 400 to $1000 \mathrm{~nm}$, relative to the effect of one concentration of soot particles, using a four-stream radiative-transfer model. Ledley and Thompson (1986), using a one-dimensional thermodynamic sea ice model, showed that soot deposition on sea ice following a nuclear disaster could significantly decrease the albedo of sea ice. The decreased albedo could result in a decrease in sea ice thickness and possibly lead to an increase in icefree conditions. Black carbon in sea ice has recently been added to global climate models; Goldenson et al. (2012) used the Community Earth System Model Version 1 (CESM1) to model the forcing due to black carbon and dust in snow and sea ice, and Holland et al. (2012) utilised the Community Climate System Model 4 to investigate the impact of melt ponds and aerosols (black carbon and dust) on Arctic sea ice. Goldenson et al. (2012) suggest black carbon could cause a decrease in Arctic sea ice thickness of $0.34 \mathrm{~m}$ in September, while Holland et al. (2012) conclude that black carbon and dust causes an annual average $0.2 \mathrm{~W} \mathrm{~m}^{-2}$ increase in shortwave absorption in Arctic sea ice over the 20th century.

The physical and optical properties of sea ice, including light scattering, absorption and density, will affect the sur- face albedo of sea ice and thus impact the extent to which black carbon will affect the albedo of sea ice. The physical properties of sea ice are sensitive to the presence of air bubbles, brine inclusions, precipitated salts and also ice structure (Perovich, 2003). Light et al. (1998), Grenfell et al. (2002) and Jacobson (2004) suggest that an increase in black carbon in sea ice (without a snow cover) from 0 to $100 \mathrm{ng} \mathrm{g}^{-1}$ will decrease albedo to $73 \%, 99 \%$ and $92 \%$ of the original values respectively at a wavelength of $500 \mathrm{~nm}$. For each of these studies the optical properties and the distribution of black carbon within the sea ice were different. Detailed comparison of the studies is therefore difficult. For example, Grenfell et al. (2002) place black carbon in only a $1 \mathrm{~cm}$ layer at the sea ice surface, which may explain the relatively small decrease in albedo reported compared to Light et al. (1998) and Jacobson (2004), who distribute black carbon evenly through the sea ice.

Sea ice is commonly covered by snow up to a few tens of centimetres thick (Weeks, 2010). Light penetrates snow and the underlying sea ice (e.g. King and Simpson, 2001; King et al., 2005); thus the optical properties of sea ice (i.e. black carbon content) will strongly influence the surface albedo of the snow. Where a thin snow cover is present black carbon in sea ice may lower the albedo of the overlying snow surface, leading to increased snow melting. The effect of black carbon in sea ice on the albedo of a thin overlying snow cover needs to be fully understood in order to understand the degree to which black carbon in sea ice may be climatically important. Warren and Wiscombe (1980) showed that $2 \mathrm{~cm}$ liquid equivalent of snow with a grain radius of $50 \mu \mathrm{m}(20 \mathrm{~cm}$ new, fluffy snow) and $8 \mathrm{~cm}$ liquid equivalent of snow with a grain radius of $200 \mu \mathrm{m}(20 \mathrm{~cm}$ fine grained, old snow) is enough for albedo to be semi-infinite or "optically thick" (within $1 \%$ of the albedo of an infinitely thick snowpack). France et al. (2011) demonstrate a snowpack needs to be greater than 3-4 $e$-folding depths $(\sim 10-20 \mathrm{~cm})$ before it is optically thick enough for its albedo to be uninfluenced by the underlying surface. However France et al. (2011) were simulating snow on a dark surface and the case of snow on sea ice will be different. Warren and Wiscombe (1980) and Brandt et al. (2005) briefly consider the effect of snow on the albedo of sea ice, with Brandt et al. (2005) suggesting that just $3 \mathrm{~cm}$ of snow on sea ice may be optically thick and therefore black carbon in sea ice would no longer be detectible in the albedo of the snow surface. The reduced albedo of snow caused by increasing black carbon in the snow layer on top of the sea ice is not considered in this study, and the interested reader is referred to the work of Reay et al. (2012)

The work presented here has two aims: firstly, to establish the response of the surface albedo of a first-year and a multi-year sea ice to an increased black carbon content; secondly, to quantify the change in albedo of snow-covered sea ice with increasing black carbon in the sea ice. The change in the albedo of the snow-covered sea ice will be quantified as a function of snow depth, snow type, sea ice type and amount 
of black carbon in the sea ice - an effect that to the authors' knowledge has not previously been quantified.

\section{Method}

A coupled atmosphere-snow-sea ice radiative-transfer model (TUV-snow) (Lee-Taylor and Madronich, 2002) was utilised to perform radiative-transfer calculations of irradiance in and above two Arctic sea ice types, which were described by the fieldwork of Grenfell and Maykut (1977). The technique for determining the response of albedo of the different sea ice types to black carbon is described in Sect. 2.1. Two different Arctic snow types (also described by Grenfell and Maykut, 1977) were placed in increasingly thick layers on the original sea ice in the TUV-snow model, also described in Sect. 2.1, to determine whether black carbon in sea ice influenced the albedo of the overlying snow. The TUVsnow model uses the DISORT code (Stamnes et al., 1988) and is described in detail by Lee-Taylor and Madronich (2002). The model parameterises sea ice and snow optical properties using only an asymmetry factor, $g$; a wavelengthindependent scattering cross-section, $\sigma_{\text {scatt }}$; a wavelengthdependent absorption cross-section, $\sigma_{\mathrm{abs}}^{+}$; and snow/sea ice density. Values of scattering and absorption cross-section for the snow and sea ice types modelled were obtained from albedo and $e$-folding depth data provided by Grenfell and Maykut (1977) using a technique described in Sect. 2.2. Section 2.2 will demonstrate that the absorption cross-section of light-absorbing impurities is consistent with black carbon and allows the amount of black carbon to be estimated.

\subsection{Calculating albedo in sea ice and snow with increasing black carbon in sea ice}

Changes in the albedo of sea ice surface with a variation in black carbon mass ratio in a $5 \mathrm{~cm}$ surface layer of the sea ice were calculated in the following manner. Albedo was calculated as the ratio of upwelling to downwelling surface irradiance $\left(\frac{\operatorname{Irr}_{\text {up }}}{\operatorname{Irr}_{\text {down }}}\right)$. Two different sea ice types (based on fieldwork of Grenfell and Maykut, 1977) were considered:

1. A first-year ice: a $155 \mathrm{~cm}$ blue sea ice layer with additional black carbon in the top $5 \mathrm{~cm}$.

2. A multi-year ice: a $150 \mathrm{~cm}$ blue sea ice layer with a top $5 \mathrm{~cm}$ granular white sea ice layer containing additional black carbon.

Grenfell and Maykut (1977) state that the melting multiyear sea ice observed in the Arctic basin was typically bluishwhite in colour (similar to the first-year blue ice) with a decomposed layer at the surface ranging from $2-15 \mathrm{~cm}$ thick (the granular white ice layer).

Secondly, the surface albedo of two different snow covers overlying the multi-year and first-year sea ice were calcu-

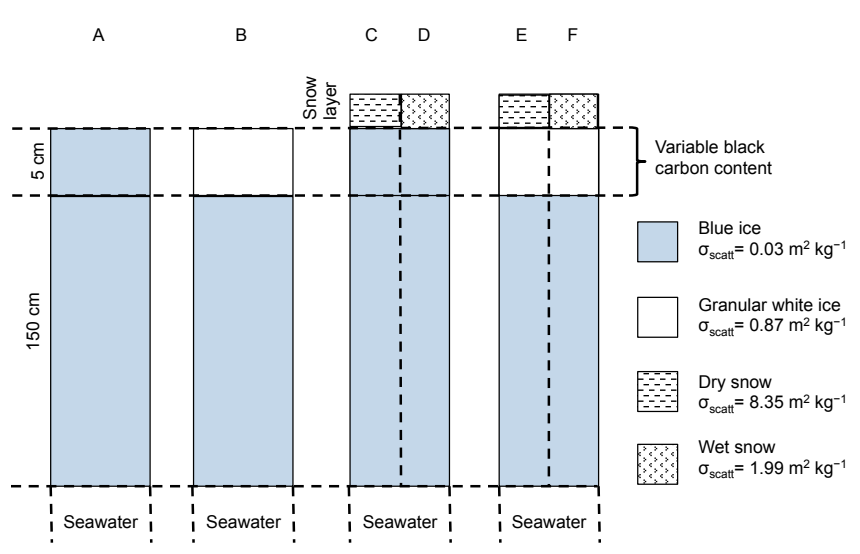

Fig. 1. Sea ice and snow configurations modelled (not to scale).

lated to observe whether a change in black carbon mass ratio in the underlying sea ice could be detected in the surface albedo of the snow. The albedo of an optically thick layer of snow on sea ice will have optical properties of snow; however the albedo of a thin layer of snow will be influenced by the optical properties of the sea ice below it. Snow coverings of $0.5,1,2,5$, and $10 \mathrm{~cm}$ of a "dry" and "wet" snow were added to both sea ice types. The dry and wet snows are based on the optical properties of dry and wet snowpacks described in Grenfell and Maykut (1977).

A summary of the snow and sea ice formations are shown in Fig. 1; black carbon mass ratios of $0,1,2,4,8,16,32,64$, $128,256,512,1024 \mathrm{ng} \mathrm{g}^{-1}$ were used. Note the black carbon is additional to any already present. Therefore total light absorption in the layer containing additional black carbon is represented by Eq. (1):

$\sigma_{\mathrm{abs}}(\lambda)=\sigma_{\mathrm{abs}}^{\mathrm{ice}}(\lambda)+\sigma_{\mathrm{abs}}^{+}(\lambda)+\sigma_{\mathrm{abs}}^{\mathrm{BC}}(\lambda)[\mathrm{BC}]$,

where $\sigma_{\text {abs }}^{\text {ice }}(\lambda)$ is the absorption cross-section for pure ice per unit mass of ice (taken from Warren and Brandt, 2008, $\sigma_{\text {abs }}^{+}(\lambda)$ is the absorption cross-section due to light-absorbing impurities already present in the snowpack, or sea ice per unit mass of snow/sea ice; $\sigma_{\mathrm{abs}}^{\mathrm{BC}}(\lambda)$ is absorption cross-section for additional black carbon per unit mass of black carbon; [BC] is the mass ratio of black carbon; and $\lambda$ is the wavelength of light. Thus when calculating the absorption cross-section, $\sigma_{\text {abs }}(\lambda)$, of the sea ice or snow from Grenfell and Maykut (1977), [BC] is zero and $\sigma_{\text {abs }}^{+}(\lambda)$ can be calculated by subtracting $\sigma_{\mathrm{abs}}^{\mathrm{ice}}(\lambda)$ from $\sigma_{\mathrm{abs}}(\lambda)$. Additional black carbon was placed in only a $5 \mathrm{~cm}$ layer at the top of the sea ice as atmospheric deposition and surface snow melt concentrate black carbon at the top of the sea ice.

The sea ice below the uppermost $5 \mathrm{~cm}$ layer had no additional black carbon, and the snow layer, where present, was also modelled with no additional black carbon.

The absorption spectrum for black carbon in an ice matrix, $\sigma_{\mathrm{abs}}^{\mathrm{BC}}(\lambda)$, shown in Fig. 2 at wavelengths 400 $700 \mathrm{~nm}$ is determined by a Mie calculation using the 
Table 1. Properties and measurement conditions of the snow and sea ice used in the study presented here. Measurement date, sky conditions, solar zenith angle, density, albedo and extinction coefficient are all from Grenfell and Maykut (1977). The values of the scattering crosssections are calculated from the albedo and extinction coefficient data.

\begin{tabular}{|c|c|c|c|c|c|c|c|c|c|}
\hline $\begin{array}{l}\text { Snow/sea ice } \\
\text { type }\end{array}$ & $\begin{array}{c}\text { Measurement } \\
\text { date }\end{array}$ & $\begin{array}{c}\text { Sky } \\
\text { conditions }\end{array}$ & $\begin{array}{l}\text { Solar zenith } \\
\text { angle/ }{ }^{\circ}\end{array}$ & $\begin{array}{l}\text { Density/ } \\
\mathrm{g} \mathrm{cm}^{-3}\end{array}$ & $\begin{array}{l}\text { Figure } \\
\text { (albedo) }\end{array}$ & $\begin{array}{c}\text { Figure } \\
\text { (extinction } \\
\text { coefficient) }\end{array}$ & $\begin{array}{c}\text { Maximum } \\
e \text {-folding } \\
\text { depth } / \mathrm{m}\end{array}$ & $\begin{array}{l}\text { Asymmetry } \\
\text { parameter, } \\
(g)\end{array}$ & $\begin{array}{l}\text { Scattering } \\
\text { cross-section } \\
\left(\sigma_{\text {scatt }}\right) / \\
\mathrm{m}^{2} \mathrm{~kg}^{-1}\end{array}$ \\
\hline Blue sea ice & 15 Jun 1972 & Clear & 50 & 0.9 & $2 d$ & $3 e$ & 1.22 & 0.95 & $0.03 \pm 0.003$ \\
\hline $\begin{array}{l}\text { Granular white } \\
\text { sea ice }\end{array}$ & 1 Jul 1974 & Clear & 65 & 0.5 & $2 b$ & $3 \mathrm{c}$ & 0.31 & 0.95 & $0.87 \pm 0.079$ \\
\hline Dry snow & 20 Jun 1972 & Clear & 50 & 0.4 & $1 \mathrm{a}$ & $3 a$ & 0.06 & 0.89 & $8.35 \pm 1.09$ \\
\hline Wet snow & 20 Jun 1972 & Diffuse & 50 & 0.47 & $1 b$ & $3 b$ & 0.12 & 0.89 & $1.99 \pm 0.23$ \\
\hline
\end{tabular}

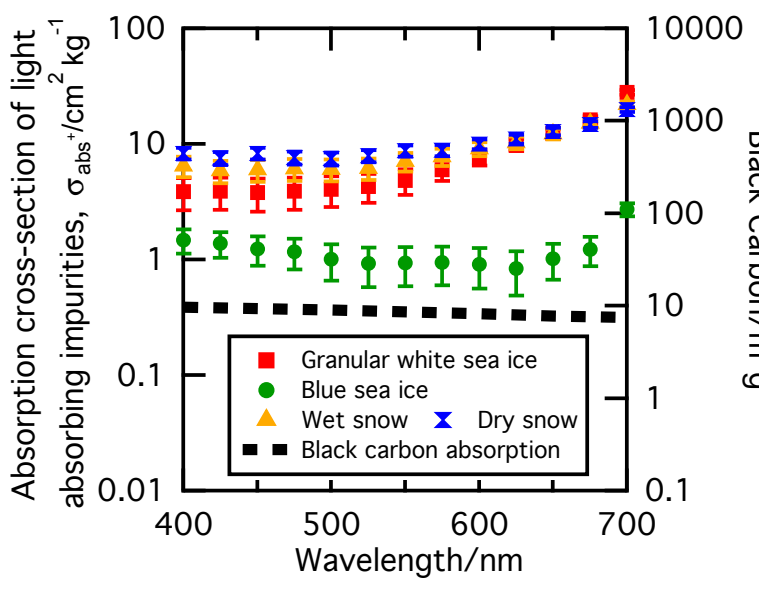

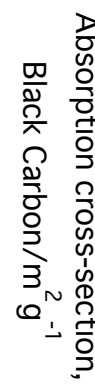

Fig. 2. Comparison of calculated absorption cross-sections for lightabsorbing impurities, $\sigma_{\text {abs }}^{+}(\lambda)$, in granular white sea ice, blue sea ice, wet snow and dry snow. Error bars show the average difference in calculated absorption values through making small changes to the data fit for obtaining these values. The absorption cross-section of black carbon and the absorption cross-section of the light-absorbing impurities is per $\mathrm{kg}$ of sea ice.

method outlined by Warren and Wiscombe (1980). The wavelength-independent refractive index of black carbon particles was chosen as $1.8-0.5 i$, with a monodisperse diameter of $0.2 \mu \mathrm{m}$ and density of $1 \mathrm{~g} \mathrm{~cm}^{-3}$; these values were justified by Warren and Wiscombe $(1985,1980)$. The wavelength-dependant refractive index of the surrounding ice was taken from Warren and Brandt (2008).

All calculations were undertaken at wavelengths 400 $700 \mathrm{~nm}$, using an eight-stream radiative-transfer calculation with a pseudo-spherical correction (Lee-Taylor and Madronich, 2002). The atmosphere had an ozone column of 300 Dobsons with no aerosol. A wavelength-independent under-ice albedo was used of 0.1 and the Earth-Sun distance was set to $1 \mathrm{AU}$. Diffuse sky conditions were used throughout the work by placing cumulus clouds in the model at a $1 \mathrm{~km}$ altitude, with an optical depth of 32 , an asymmetry parameter of 0.85 and a single-scattering albedo of 0.9999 . Diffuse sky conditions were used to calculate surface albedo independent of solar zenith angle. The albedo of sea ice and snow depend on the solar zenith angle but are not dependant on the absolute irradiance of incident radiation. The TUV-snow model has been previously used for coupled atmosphere-sea ice radiative-transfer calculations (e.g. King et al., 2005), multiple times for coupled atmospheresnow calculations (e.g. Fisher et al., 2005; Beine et al., 2006; France et al., 2007; France et al., 2010a,b, 2011, 2012; Reay et al., 2012), and validated in artificial laboratory snow experiments (Phillips and Simpson, 2005). The work presented here is the first time the TUV-snow model has been configured to a coupled atmosphere-snow-sea ice system.

\subsection{Obtaining scattering and absorption cross-section values for snow and sea ice}

Grenfell and Maykut (1977) conducted measurements of light extinction coefficient (reduction in flux within a scattering medium, wavelengths $400-800 \mathrm{~nm}$ ) and albedo (wavelengths 400-1000 nm) for melt ponds, snow on sea ice, and bare sea ice on first-year sea ice near Point Barrow, Alaska, and on multi-year ice near Fletcher's Ice Island in the Beaufort Sea. Two sea ice types and two snow types were selected from the data of Grenfell and Maykut (1977) as representative for the study presented here and are described in the previous section and in Table 1 and Fig. 1. Using the albedo and extinction coefficient data of the two sea ice types and two snow types (see Table 1), values of the scattering, $\sigma_{\text {Scatt }}(\lambda)$, and absorption, $\sigma_{\text {abs }}^{+}(\lambda)$, cross-section were calculated using a method developed and described in detail by Lee-Taylor and Madronich (2002) and very briefly described here. Radiative-transfer calculations of albedo and $e$-folding depths for a range of values of scattering and absorption cross-section were undertaken using the TUV-snow model. The sea ice was modelled as $1 \mathrm{~m}$ thick, with 24 layers, and 
the atmosphere was aerosol free. Table 1 lists the sky conditions, measurement date (used to calculate Earth-Sun distance), asymmetry factor $(g)$, sea ice/snow density and solar zenith angle for each sea ice/snowpack modelled. The albedo and $e$-folding depth are interpolated to find unique values for scattering and absorption at a specific wavelength that concur with Grenfell and Maykut (1977) field measurements of both albedo and extinction coefficient. The $e$-folding depth, $\epsilon$, is related to extinction coefficient, $\kappa$, by Eq. (2). The technique has previously been used for sea ice by King et al. (2005) and for snow, e.g. by France et al. $(2011,2012)$.

$\epsilon=\frac{1}{\kappa}$

The calculated scattering cross-sections for each sea ice and snow type, shown in Table 1, were assumed wavelength independent (Lee-Taylor and Madronich, 2002). The calculated absorption cross-section of light-absorbing impurities for each sea ice and snow type were wavelength dependent; these are shown in Fig. 2.

The unique solutions found by the above method are a result of using light penetration data and reflectivity data for the same sea ice or snowpack. The unique solution is demonstrated in Lee-Taylor and Madronich (2002) in their Fig. 1, where the intersection of two curves on a plot of, $\sigma_{\text {scatt }}$ against, $\sigma_{\text {abs }}$ (one curve representing constant albedo and the other curve representing constant $e$-folding depth) is the unique solution. The intersection and thus values of $\sigma_{\text {scatt }}$ and $\sigma_{\mathrm{abs}}$ may be sensitive to the initial fit to the reflectivity and $e$-folding depth data, propagating the uncertainty results in the error bars in Fig. 2.

The asymmetry parameter, $g$, was held constant in this study at a value of 0.95 for the sea ice and 0.89 for snow. It is not always possible to find a unique solution for $\sigma_{\text {scatt }}, \sigma_{\text {abs }}$ and $g$. Adopting the approach of Lee-Taylor and Madronich (2002), $g$ was held constant and $\sigma_{\text {scatt }}$ and $\sigma_{\text {abs }}$ varied. France et al. (2012) undertook a sensitivity study of changing $g$ between reasonable limits for snow based on the work of Warren and Wiscombe (1980), and found the value of $\sigma_{\text {scatt }}$ and $\sigma_{\text {abs }}^{+}$to be relatively insensitive to the value of $g$ for a snowpack in Barrow, Alaska. Repeating a similar study to France et al. (2012) for the blue sea ice and granular white sea ice yields the values presented in Table. 2.

\section{Results}

The results section will describe how the effect on surface albedo of additional black carbon in a surface layer of sea ice varies with sea ice type (Sect. 3.1) and snow cover (Sect. 3.2).

\subsection{Variation in albedo with increasing black carbon content in first-year and multi-year sea ice}

Figure 3 shows the diffuse surface albedo of the first-year and multi-year sea ice at wavelengths $400-700 \mathrm{~nm}$ with ad-

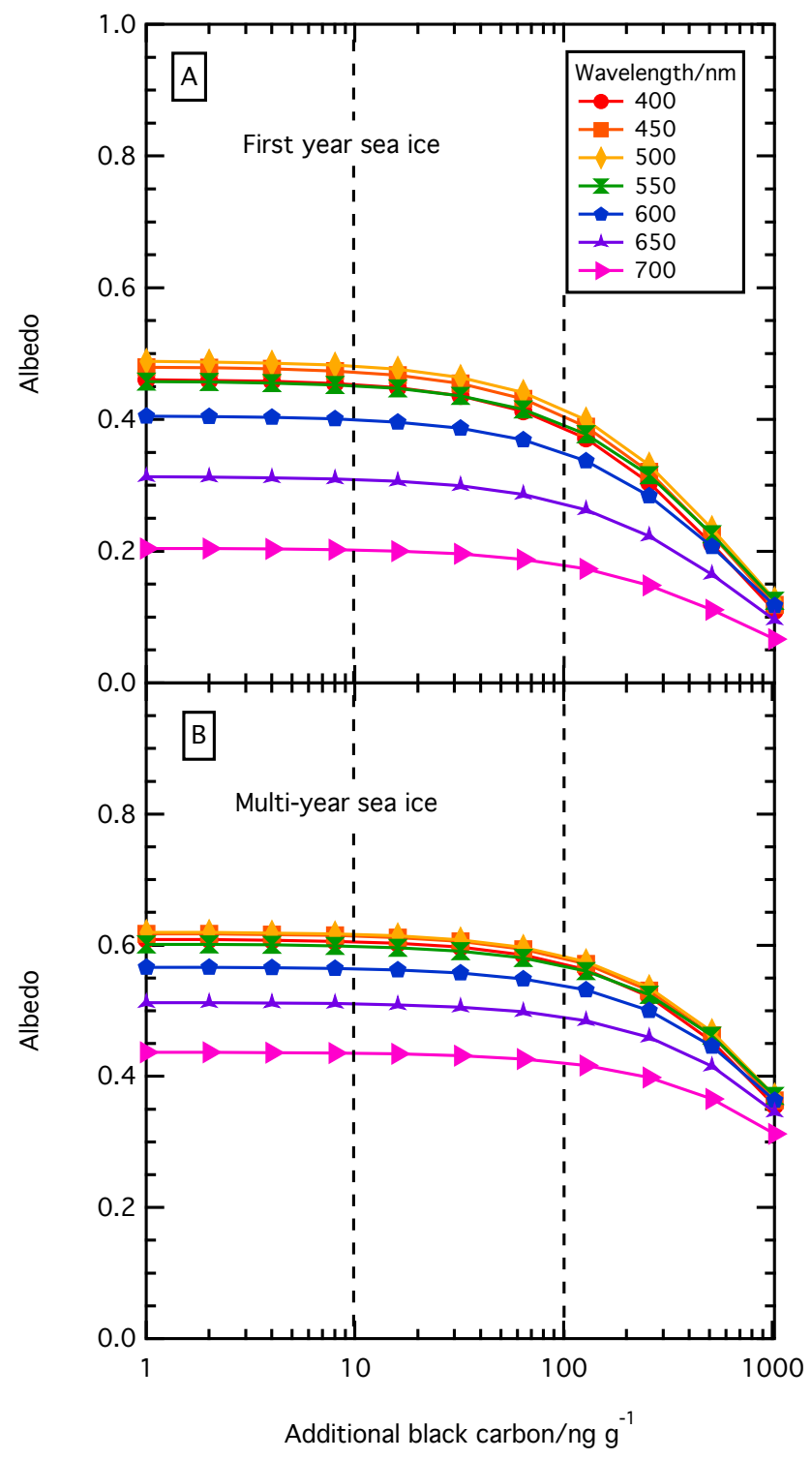

Fig. 3. (A) Albedo with increasing additional black carbon content from 1 to $1024 \mathrm{ng} \mathrm{g}^{-1}$, evenly distributed in the top $5 \mathrm{~cm}$ of $155 \mathrm{~cm}$ of typical first-year sea ice. (B) Albedo with increasing black carbon content from 1 to $1024 \mathrm{ngg}^{-1}$, evenly distributed in the top $5 \mathrm{~cm}$ layer of $155 \mathrm{~cm}$ of a typical multi-year sea ice.

ditional black carbon, ranging from 1 to $1024 \mathrm{ng} \mathrm{g}^{-1}$, in a top $5 \mathrm{~cm}$ layer. For both sea ice types, as black carbon content increases the albedo decreases. For a black carbon increase from 1 to $8 \mathrm{ng} \mathrm{g}^{-1}$, albedo decreases to $98.7 \%$ of the initial value for first-year sea ice and decreases to $99.7 \%$ of the initial value in the multi-year sea ice. Thus the albedo of firstyear sea ice is more sensitive to additional black carbon than the multi-year sea ice.

The decrease in albedo with increasing mass ratio of black carbon is non-linear; for example, in the first-year ice (Fig. 3a) a doubling of additional black carbon from 2 to 
Table 2. Variation in derived $\sigma_{\mathrm{scatt}}$ and $\sigma_{\mathrm{abs}}^{+}$of the blue sea ice and granular white sea ice from variation of the asymmetry parameter, $g$.

\begin{tabular}{ccccc}
\hline $\begin{array}{c}\text { Asymmetry } \\
\text { parameter, } g\end{array}$ & \multicolumn{2}{c}{$\begin{array}{c}\text { Blue sea ice } \\
\lambda=550 \mathrm{~nm}\end{array}$} & \multicolumn{2}{c}{$\begin{array}{c}\text { Granular white sea ice } \\
\lambda=550 \mathrm{~nm}\end{array}$} \\
& $\sigma_{\text {scatt }} / \mathrm{m}^{2} \mathrm{~kg}^{-1}$ & $\sigma_{\mathrm{abs}}^{+} / \mathrm{cm}^{2} \mathrm{~kg}^{-1}$ & $\sigma_{\text {scatt }} / \mathrm{m}^{2} \mathrm{~kg}^{-1}$ & $\sigma_{\text {abs }}^{+} / \mathrm{cm}^{2} \mathrm{~kg}^{-1}$ \\
\hline 0.945 & 0.027 & 1.037 & 0.665 & 4.272 \\
0.95 & 0.03 & 1.037 & 0.726 & 4.272 \\
0.955 & 0.034 & 1.035 & 0.814 & 4.272 \\
\hline
\end{tabular}

$4 \mathrm{ngg}^{-1}$ leads to a decrease in albedo to $99.7 \%$ of the albedo value at $2 \mathrm{ng} \mathrm{g}^{-1}$, but a doubling of additional black carbon from 512 to $1024 \mathrm{ngg}^{-1}$ results in a decrease in albedo to $54 \%$ of the albedo value at $512 \mathrm{ng} \mathrm{g}^{-1}$. For the multi-year ice (Fig. 3b) a doubling of black carbon from 2 to $4 \mathrm{ngg}^{-1}$ leads to a decrease in albedo to $99.9 \%$, but a doubling from 512 to $1024 \mathrm{ngg}^{-1}$ leads to a decrease in albedo to $79 \%$ at a wavelength of $500 \mathrm{~nm}$. As the amount of black carbon increases, the wavelength dependence of the albedo decreases; similar behaviour has been observed and explained for snowpacks (Reay et al., 2012).

\subsection{Effect of snow cover and type on the influence of black carbon in sea ice on surface albedo}

Figure 4 shows surface albedo, with snow cover between 0 and $10 \mathrm{~cm}$ thick as a function of additional mass ratio of black carbon in sea ice at a wavelength of $500 \mathrm{~nm}$. An optically thick snow layer (physically $1 \mathrm{~m}$ thick) is shown in Fig. 4 for comparative purposes. Two results are immediately obvious from Fig. 4 . The addition of a thin layer $(0.5 \mathrm{~cm})$ of snow on sea ice can drastically increase the albedo of the surface; this is not a surprising result and has been suggested by Brandt et al. (2005). Secondly, the effect of a layer of snow in mitigating the response of albedo to black carbon in sea ice is quantified for the first time. A layer of $2-5 \mathrm{~cm}$ of snow is effectively enough to mask any change in albedo owing to additional black carbon in sea ice. However whilst $2-5 \mathrm{~cm}$ of snow cover is enough to mask any change in additional black carbon in the sea ice, it is not thick enough to be wholly responsible for surface albedo. The asymptotic $e$ folding depths of the wet and dry snowpacks are $12 \mathrm{~cm}$ and $6 \mathrm{~cm}$ at a wavelength of $500 \mathrm{~nm}$, and previously it has been shown that a snowpack needs to be greater than 3-4e-folding depths before it is optically thick enough to be uninfluenced by the underlying layer (e.g. France et al., 2011).

Figure 4 shows dry snow has a much greater impact on mitigating the effect of black carbon in sea ice on surface albedo than wet snow - most noticeably observed with the addition of a layer of snow of $0.5 \mathrm{~cm}$ thickness. With an increase in snow thickness from 5 to $10 \mathrm{~cm}$ of dry snow there is only a very small change in albedo calculated; with the same wet snow addition there is a noticeable difference in the albedo calculated, suggesting a greater thickness of wet snow would be required for the snow layer to be optically thick. The increase in surface albedo owing to the addition of snow to sea ice is greater for the first-year ice than the multi-year ice. The initial albedo of the first-year ice is lower than the albedo of the multi-year ice, and therefore a larger change in albedo occurs with addition of snow.

\section{Discussion}

The following discussion will focus on the light-absorbing impurities in the sea ice, the response of albedo to black carbon depending on sea ice type, and on the effect of snow cover, and it finishes with a discussion on the limitations and future possibilities of the study.

\subsection{Absorption cross-sections of snow and sea ice}

Figure 2 shows the absorption cross-sections for the lightabsorbing impurities in the snow and sea ice types determined from the albedo and extinction coefficient data of Grenfell and Maykut (1977). Figure 2 shows variation with wavelength to be reasonably flat, but with a slight increase with longer wavelengths. The lack of a strong wavelength dependance may be interpreted as consistent with black carbon being the dominant light-absorbing impurity. The absorption cross-section of black carbon is plotted in Fig. 2 for comparison.

The mass ratio of black carbon in each sea ice and snowpack can be estimated form the data in Fig. 2 using Eq. (3) as described in France et al. (2012) and Reay et al. (2012):

$[\mathrm{BC}]=\frac{\sigma_{\mathrm{abs}}^{+}}{\sigma_{\mathrm{BC}}}$,

where $\sigma_{\mathrm{abs}}^{+}$is the absorption cross-section owing to lightabsorbing impurities over the wavelength range $400-600 \mathrm{~nm}$ in Fig. 2, $\sigma_{\mathrm{BC}}$ is the absorption cross-section for black carbon $\left(\sim 10 \mathrm{~m}^{2} \mathrm{~g}^{-1}\right.$, and shown in Fig. 2$)$, and [BC] is the black carbon mass ratio.

The granular white ice has an estimated equivalent black carbon mass ratio of $48 \mathrm{ngg}^{-1}$, the blue sea ice has $11.1 \mathrm{ng} \mathrm{g}^{-1}$, the wet snow has $63 \mathrm{ng} \mathrm{g}^{-1}$ and the dry snow has $83 \mathrm{ng} \mathrm{g}^{-1}$. Although not improbable, these values are large compared to most previous literature reporting black carbon 


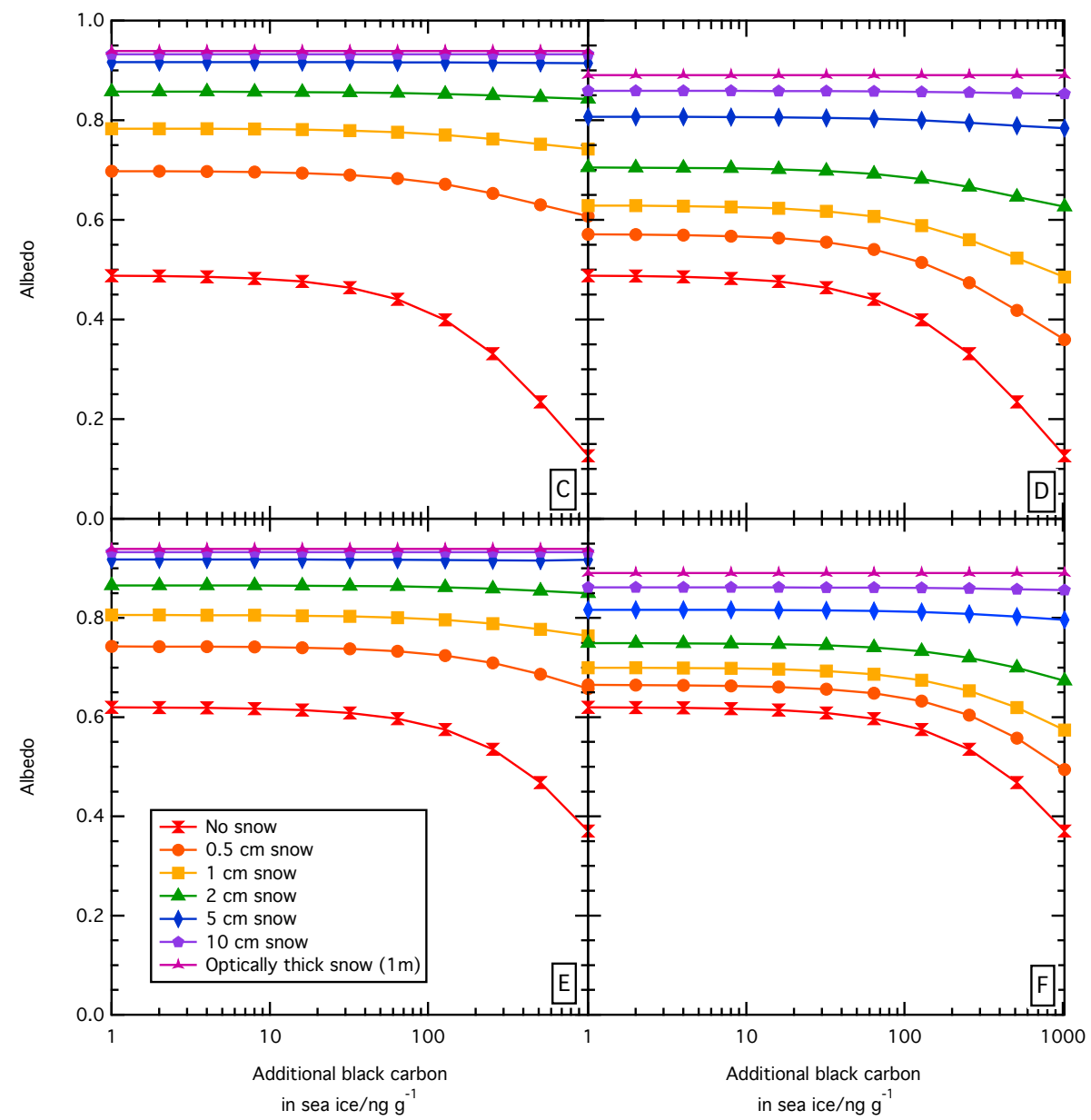

Fig. 4. Albedo of snow surface at $500 \mathrm{~nm}$ with different thicknesses of snow cover overlying sea ice. (C) dry snow on first-year ice, (D) wet snow on first-year ice, $(\mathbf{E})$ dry snow on the multi-year ice, $(\mathbf{F})$ wet snow on multi-year ice.

values in snow and sea ice. Clarke and Noone (1985) report typical black carbon mass ratios in Arctic snow, ranging from $23 \mathrm{ngg}^{-1}$ at Barrow, Alaska, to $45.5 \mathrm{ngg}^{-1}$ at Alert, Canada. Grenfell et al. (2002) report values of black carbon mass ratio in Arctic sea ice of $5.5 \mathrm{ng} \mathrm{g}^{-1}$. Figure $6 \mathrm{c}$ of Warren and Wiscombe (1980) shows they required $300 \mathrm{ng} \mathrm{g}^{-1}$ of black carbon to reproduce the albedo of the snow presented by Grenfell and Maykut (1977), and suggest that the large values of mass ratio of black carbon may be due to pollution from the T3 camp. Note 3 on page 2732 of Warren and Wiscombe (1980) suggests that a value of $150 \mathrm{ng} \mathrm{g}^{-1}$ is actually more accurate based on a more realistic density of the black carbon absorber. The mass ratio of black carbon in the snow presented by Warren and Wiscombe (1980) is still approximately twice those values presented here. To reconcile the different values of black carbon requires comparison of the two techniques of determining black carbon mass ratio. The calculations presented here use the same optical properties of the black carbon as note 3 in Warren and Wiscombe (1980) and further adopted by Warren (1982). The radiative-transfer calculations of Warren and Wiscombe (1980) reproduce the albedo data of Grenfell and Maykut (1977) only, whereas the work presented here reproduces the albedo and light penetration data. The work of Warren and Wiscombe (1980) requires an assumption of grain size based on absorption only by ice at a wavelength of $900 \mathrm{~nm}$, and apparently assumes no absorption by impurity at $900 \mathrm{~nm}$, whereas the radiativetransfer calculation employed here requires no knowledge of the grain size. Thus the radiative-transfer calculation here may be a truer representation of the equivalent mass ratio of black carbon as it is more constrained by experimental data, reproduces albedo and light penetration data and does not require assumption of grain size.

In the work presented here it is likely that not all absorption by light-absorbing impurities is due to black carbon, and another light-absorbing impurity is present. The presence of other light-absorbing impurities could explain the increase in absorption cross-section with wavelength. Other light-absorbing impurities present in sea ice and snow could include sediments, atmospheric dust, algae and HUmic-LIke 
Substances (HULIS) (e.g. Light et al., 1998; France et al., 2012). France et al. (2012) suggest algae as a possibility for the increase in absorption observed at longer wavelengths. Light et al. (1998, Fig. 13a) and Perovich (2009, Fig. 3.6.2) show how ice algae absorption increases at wavelengths $600-650 \mathrm{~nm}$. However ice algae absorption also peaks at wavelengths from 400 to $500 \mathrm{~nm}$ and decreases from 650 to $700 \mathrm{~nm}$ : trends that are not seen in the absorption crosssection in Fig. 2. The absorption of sediments and atmospheric dust is also shown in Light et al. (1998, Fig. 13a) and Perovich (2009, Fig. 3.6.2); (where atmospheric dust is assumed to have identical optical properties to sediments) these steadily increase from 550 to $700 \mathrm{~nm}$, so there may also be sediment or dust in the snow and sea ice studied. Doherty et al. (2010) conclude that $40 \%$ of the light absorption in their filtered snow and sea ice samples was due to species other than black carbon.

\subsection{Variation in the impact of black carbon with sea ice type}

Figure 3 surprisingly shows that the albedo of the sea ice surface is insensitive to additional black carbon mass ratios under $100 \mathrm{ng} \mathrm{g}^{-1}$ added in the top $5 \mathrm{~cm}$ of the sea ice. It should be stressed that it is additional black carbon to any black carbon already present and the albedo of the sea ice is sensitive to absolute changes in black carbon mixing ratios of 1$100 \mathrm{ng} \mathrm{g}^{-1}$. Figure 3 also shows that the impact of additional black carbon on surface albedo is dependant on the sea ice type, with the first-year ice showing a much more sensitive response to black carbon than the multi-year ice. The multiyear ice consists of the granular white ice on top of a blue ice, while the first-year ice is just blue ice. The granular white ice has larger values for the scattering and absorption crosssections than the blue ice.

Similar differences in the effect of black carbon on surface albedo with sea ice type are observed in previous modelling of black carbon in sea ice. Light et al. (1998) used a structural-optical model in combination with a four-stream radiative-transfer model to calculate the effects of increased soot concentration in a multi-year frozen sea ice, suggesting an increase from 0 to $100 \mathrm{ngg}^{-1}$ of black carbon in the sea ice will decrease the albedo to $73 \%$ of the original value at a wavelength of $500 \mathrm{~nm}$. However, Grenfell et al. (2002) utilised a multi-layer four-stream radiative-transfer model to investigate effects of varying concentrations and vertical distribution of soot on albedo, transmissivity, and internal heating of the ice, only reporting a decrease in albedo to $99 \%$ of the original value for an increase from 0 to $100 \mathrm{ng} \mathrm{g}^{-1}$ of black carbon in the top $1 \mathrm{~cm}$ layer of their sea ice. Differing as well, calculations presented here suggest a decrease in albedo to $96 \%$ for multi-year ice and $91 \%$ for first-year ice for an additional black carbon increase of $100 \mathrm{ngg}^{-1}$. The greatest albedo difference is therefore observed by Light et al. (1998), who model a sea ice with scat- tering cross-section values of $0.654,1.46$, and $0.96 \mathrm{~m}^{2} \mathrm{~kg}^{-1}$ in three layers from the top, $0.05,0.2$, and $2.6 \mathrm{~m}$ thick respectively. These values compare with a scattering crosssection used by Grenfell et al. (2002) of $0.3 \mathrm{~m}^{2} \mathrm{~kg}^{-1}$ in the upper $4 \mathrm{~cm}$, and $0.0375 \mathrm{~m}^{2} \mathrm{~kg}^{-1}$ for the lower $150 \mathrm{~cm}$, in contrast to the scattering cross-sections used for our work of $0.03 \mathrm{~m}^{2} \mathrm{~kg}^{-1}$ for blue ice and $0.87 \mathrm{~m}^{2} \mathrm{~kg}^{-1}$ for granular white ice. The results presented here suggest that a large value of the scattering cross-section may result in black carbon having less effect on albedo. However, Light et al. (1998) use large scattering cross-sections (relative to those used in this study) and see a relatively large change in albedo with increasing black carbon, suggesting other factors may play a key role in determining the albedo response of sea ice. Different studies distribute the black carbon in different positions in the sea ice, which limits comparability between studies; Grenfell et al. (2002) place black carbon in a surface 1 $\mathrm{cm}$ layer, Light et al. (1998) evenly distributed black carbon throughout the sea ice, and in the work presented here black carbon is situated in a $5 \mathrm{~cm}$ surface layer.

\subsection{The role of snow and snow type in the influence of black carbon in sea ice on surface albedo}

To the authors' knowledge previous research into the effects of black carbon on surface albedo of sea ice has assumed snow-free conditions typical of late and early periods in the sea ice season; e.g. Light et al. (1998) mention their study only being valid during the ablation season when snow cover is eliminated. Sea ice is predominately snow covered. Figure 4 demonstrates the extent to which even a thin snow cover $(<1 \mathrm{~cm})$ can diminish the effect that black carbon in the sea ice has on the surface albedo. Figure 4 demonstrates that additional black carbon in the sea ice changes the surface albedo up to $5 \mathrm{~cm}$ of snow and the snow is not optically thick until the snow is over $10 \mathrm{~cm}$ thick. The snow or sea ice is described as optically thick when increasing its thickness does not result in a change in surface reflectivity. France et al. (2011) state that optical thickness was typically when the snow thickness is 3-4e-folding depths but for snow on sea ice a practical definition of optically thick appears to be approximately one $e$-folding depth of snow. The difference can be rationalised as optical thickness for landbased snowpacks occurs where there is no change in surface albedo with increasing snow thickness owing to the influence of a dark ground surface, whereas for snow on sea ice the albedo difference between snow and sea ice is much smaller than for dark soil and snow. Albedo of optically thick snow ( $1 \mathrm{~m}$ thick) is also shown in Fig. 4 for comparison. Brandt et al. (2005) suggest from their results of studying albedo of Antarctic sea ice that a snow covering of $3 \mathrm{~cm}$, or in some cases just $1 \mathrm{~cm}$, can be classed as optically thick snow. The results presented here agree that a thin snow covering will greatly increase the albedo but a snow cover greater than $3 \mathrm{~cm}$ would be needed to be described as optically thick. 
Figure 4 also shows how the influence of black carbon in sea ice on surface albedo is effected by the type of snow cover. Dry snow has a greater effect at mitigating the impact of black carbon in sea ice on surface albedo compared to the wet snow. The dry snow is a more scattering medium per unit depth, evidenced by the $e$-folding depths given in Table 1 . Therefore a smaller depth is required to be optically thick.

To understand the degree to which black carbon in sea ice may affect surface albedo, knowledge of snow depth over sea ice and its variation seasonally and spatially is essential. Snow depth measurements over sea ice have been reported both from ground measurements (e.g. Warren et al., 1999; Massom et al., 2001) and more recently through satellite and airborne measurements (e.g Kanagaratnam et al., 2007; Kwok and Cunningham, 2008; Kwok et al., 2011; Galin et al., 2012). Two studies provide an overview of snow thicknesses over sea ice. Warren et al. (1999) present a comprehensive data set of Arctic Ocean snow cover from measurements of snow depth and density over $37 \mathrm{yr}$ at the Soviet drifting stations, while Massom et al. (2001), using data collected over $10 \mathrm{yr}$, review snow thickness and snow type of Antarctic snow on sea ice. Arctic sea ice is mostly free of snow during the second half of July and all of August. Therefore during these months black carbon in sea ice would affect surface albedo. Snow thickness reaches a maximum in the Arctic in May, when the average depth is $34.4 \mathrm{~cm}$ (Warren et al., 1999). In Antarctica mean snow thickness varies both seasonally and regionally due to differences in precipitation regimes and the age of the underlying ice (Massom et al., 2001). In March, in East Antarctica, $20 \%$ of the sea ice is predominately snow free, and less than $10 \%$ of the snow cover is thicker than $10 \mathrm{~cm}$. By August (winter), snow thickness is typically $10-20 \mathrm{~cm}$, but $10 \%$ of the sea ice remains snow free (Massom et al., 2001). Although snow on sea ice would appear to predominately mask the effects of black carbon in sea ice in both the Antarctic and Arctic, the effect of black carbon on albedo of sea ice is important for a few of months of the year, in both the Antarctic and Arctic. These months would be following a period of snow melt over sea ice where black carbon may be concentrated onto the sea ice surface from meltwater (Grenfell et al., 2002). Doherty et al. (2010) measured spatial variation of black carbon through sea ice cores taken on sea ice in the southern Canadian basin, suggesting black carbon is concentrated near the surface following snowmelt. Further work on the distribution of black carbon in sea ice would be useful. The months of bare sea ice would also coincide with higher surface irradiance owing to smaller solar zenith angles, so melting may be exacerbated, as more radiation is absorbed by black carbon.

\subsection{Potential limitations in the model and future research possibilities}

The work presented here has several limitations: firstly, the method for obtaining scattering and absorption crosssections of sea ice and snow; secondly, the absorption spectra of black carbon; thirdly, the physical characteristics of the black carbon; and fourthly, the age of the field data on which these data are based. These limitations will now be discussed.

There is a source of uncertainty in the method for obtaining the absorption and scattering cross-sections from $e$-folding depth and albedo data (e.g. Lee-Taylor and Madronich, 2002; King et al., 2005; France et al., 2011, 2012). Figure 2 has error bars for the calculated values of absorption cross-section for light-absorbing impurities, and Table 1 shows estimates of uncertainty for the calculated scattering cross-section values. The uncertainty bars in Fig. 2 represent the range of values of the absorption cross-section that are derived from an optimal fit of the albedo and extinction coefficient data from Grenfell and Maykut (1977), while holding the asymmetry parameter, $g$, and density constant. All values of scattering cross-section are within $13 \%$ of our reported value, and the majority of absorption values are within $10 \%$ of our reported value. Figure 5 shows a comparison between our modelled albedo and the original albedo measured by Grenfell and Maykut (1977) for each snow and sea ice type. A reasonable fit between the albedo for each snow/sea ice type is observed, with all modelled albedo being within $10 \%$ of the measured value and the two snows being within $2 \%$ of the measured albedo.

The calculation to obtain values of the scattering and absorption cross-sections assumes all light-absorbing impurities are due to black carbon. In reality impurities are likely to include other substances, for example HULIS, dust, sediment and marine algae that would contribute to absorption in the sea ice. The very large value of the absorption crosssection of black carbon compared to other substances often results in black carbon being the dominant absorbing impurity. The black carbon properties used for our calculations (refractive index, size and density) are taken to be a standard proxy for black carbon and are based on calculations by Warren and Wiscombe (1980, 1985). Bohren (1986) reviewed uncertainties in the black carbon "proxy" suggesting three main limitations. Firstly Bohren (1986) suggests it is unlikely all soot particles are spherical, as assumed, with differently shaped particles potentially having different absorption efficiencies; e.g. plate-like particles would have an absorption cross-section twice as large as spherical particles. Secondly the refractive index utilised by Warren and Wiscombe (1980) $(1.8+0.5 i)$ has a factor of 5 uncertainty in the imaginary part (Roessler and Faxvog, 1980). Lastly the particle porosity is unknown and porous particles will be more absorbent than solid particles. The density of black carbon particles is discussed in Warren and Wiscombe (1985). France et al. (2012) recently demonstrated a good correlation between their black 


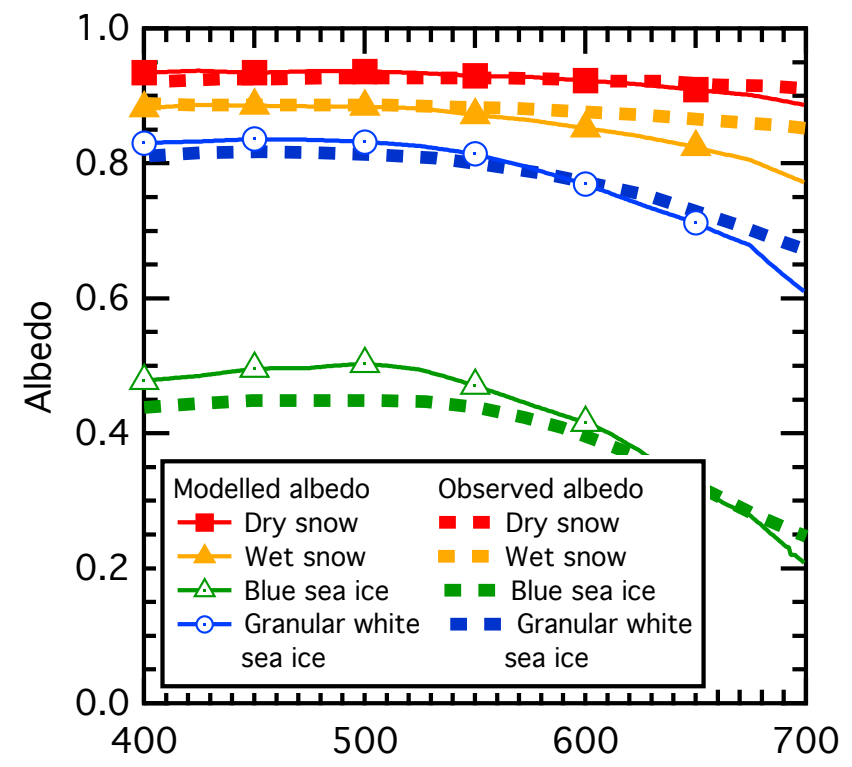

Wavelength/nm

Fig. 5. Comparison of measured albedo by Grenfell and Maykut (1977) (dashed line) with albedo modelled in the study presented here (markers and solid line).

carbon absorption cross-section (used in this study) and the experimentally measured absorption cross-section of black carbon reviewed by Bond and Bergstrom (2006).

The optical properties of the sea ice and snow are based on a field study of snow and sea ice from the 1970s (Grenfell and Maykut, 1977). The black carbon content of this sea ice may not be representative of present-day sea ice, and the study refers to one location on the sea ice, north of Barrow, Alaska. Thus the results in this paper must be interpreted within this caution. However, the Grenfell and Maykut (1977) study is exceptional in the quality and amount of data it produced. To derive scattering and absorption cross-sections for the study presented here required monochromatic measurements of reflectivity, and light penetration over a wide range of wavelengths, sea ice types and snow types. Such a large data set recorded in one study makes it an ideal data set. Confidence in using the Grenfell and Maykut (1977) study also comes from the work of Lee-Taylor and Madronich (2002). LeeTaylor and Madronich (2002) also calculated scattering and absorption cross-sections of the snowpacks reported in Grenfell and Maykut (1977) along with more modern studies of other snowpacks. The values obtained in the Lee-Taylor and Madronich (2002) study suggest they can potentially be considered contemporary with the present century. However, the black carbon content of the snowpack derived from the work by Grenfell and Maykut (1977) does appear large compared to the exhaustive study by Doherty et al. (2010).

\section{Conclusions}

Absorption and scattering cross-section coefficients were calculated for a first-year and multi-year sea ice and dry and wet snow types suggesting black carbon is the dominating absorbing impurity. Estimated black carbon mass ratios for the sea ice and snow are larger than previously reported, suggesting the presence of a secondary absorbing impurity which is likely to be atmospheric dust/sediment. Radiativetransfer calculations demonstrate the albedo of sea ice is surprisingly unresponsive to additional black carbon additions up to $100 \mathrm{ng} \mathrm{g}^{-1}$ with a decrease in albedo to $99.7 \%$ of the original value of albedo due to an addition of $8 \mathrm{ng} \mathrm{g}^{-1}$ black carbon in multi-year year sea ice compared to an albedo decrease to $98.7 \%$ for the same black carbon mass ratio increase in first-year sea ice. This highlights that the first-year sea ice proved more responsive to black carbon additions. The first-year sea ice is a less scattering environment than the multi-year sea ice. Thus, a less scattering sea ice environment may be more responsive to additional black carbon. As sea ice is predominately snow covered, the influence of an overlying snow cover at mitigating the effects of black carbon in the sea ice surface layer was also investigated. A $0.5 \mathrm{~cm}$ layer of snow greatly diminishes the effect of black carbon in sea ice on snow surface albedo. A $2-5 \mathrm{~cm}$ layer (less than half the $e$-folding depth of snow) is enough to "mask" any change in surface albedo owing to additional black carbon in the sea ice, but not thick enough to ignore the underlying sea ice. For snow on sea ice a practical definition of optically thick appears to be approximately one $e$-folding depth of snow. Although the effects of black carbon in sea ice are limited to when snow cover is below $2-5 \mathrm{~cm}$, black carbon is still critical in the sea ice system because as soon as snow is thin enough for black carbon in the sea ice to affect surface albedo it will exacerbate snow melting, leading to longer snow-free conditions and greater sea ice melting. Furthermore the period of the year when sea ice is snow free coincides with the smallest solar zenith angles, i.e. when the solar radiation is greatest, so the influence of black carbon will be larger.

Acknowledgements. M. D. King thanks NERC for support under Grants NE/F004796/1 and NE/F010788/1. A. A. Marks is supported by a Thomas Holloway Fellowship.

Edited by: R. Lindsay

\section{References}

Barry, R. G.: The parameterization of surface albedo for sea ice and its snow cover, Prog. Phys. Geo., 20, 63-79, 1996.

Beine, H. J., Amoroso, A., Dominé, F., King, M. D., Nardino, M., Ianniello, A., and France, J. L.: Surprisingly small HONO emissions from snow surfaces at Browning Pass, Antarctica, Atmos. Chem. Phys., 6, 2569-2580, doi:10.5194/acp-6-2569-2006, 2006. 
Bohren, C.: Applicability of effective-medium theories to problems of scattering and absorption by nonhomogeneous atmospheric particles, J. Atmos. Sci., 43, 468-475, 1986.

Bond, T. C. and Bergstrom, R. W.: Light Absorption by Carbonaceous Particles: An Investigative Review, Aero. Sci. Tech., 40, 27-67, 2006.

Brandt, R., Warren, S., Worby, A., and Grenfell, T.: Surface albedo of the Antarctic sea ice zone, J. Climate, 18, 3606-3622, 2005.

Chýlek, P., Ramaswamy, V., and Srivastava, V.: Albedo of sootcontaminated snow, J. Geophys. Res., 88, 837-843, 1983.

Clarke, A. and Noone, K.: Soot in the Arctic snowpack: A cause for perturbations in radiative transfer, Atmos. Environ., 19, 20452053, 1985.

Curry, J., Schramm, J., and Ebert, E.: Sea ice-albedo climate feedback mechanism, J. Climate, 8, 240-247, 1995.

Dittmar, T.: The molecular level determination of black carbon in marine dissolved organic matter, Org. Geochem., 39, 396-407, 2008.

Doherty, S. J., Warren, S. G., Grenfell, T. C., Clarke, A. D., and Brandt, R. E.: Light-absorbing impurities in Arctic snow, Atmos. Chem. Phys., 10, 11647-11680, doi:10.5194/acp-1011647-2010, 2010.

Fisher, F., King, M., and Lee-Taylor, J.: Extinction of UV-visible radiation in wet midlatitude (maritime) snow: Implications for increased NOx emission, J. Geophys. Res., 110, D21301, doi:10.1029/2005JD005963, 2005.

Flanner, M., Zender, C., Randerson, J., and Rasch, P.: Present-day climate forcing and response from black carbon in snow, J. Geophys. Res, 112, D11202, doi:10.1029/2006JD008003, 2007.

France, J., King, M., and Lee-Taylor, J.: Hydroxyl (OH) radical production rates in snowpacks from photolysis of hydrogen peroxide $\left(\mathrm{H}_{2} \mathrm{O}_{2}\right)$ and nitrate $\left(\mathrm{NO}_{3}^{-}\right)$, Atmos. Environ., 41, 5502-5509, 2007.

France, J., King, M., and Lee-Taylor, J.: The importance of considering depth-resolved photochemistry in snow: a radiativetransfer study of $\mathrm{NO}_{2}$ and $\mathrm{OH}$ production in $\mathrm{Ny}$-Alesund (Svalbard) snowpacks, J. Glaciol., 56, 655-662, 2010a.

France, J., King, M., and MacArthur, A.: A photohabitable zone in the martian snowpack? A laboratory and radiative-transfer study of dusty water-ice snow, Icarus, 207, 133-139, $2010 \mathrm{~b}$.

France, J. L., King, M. D., Frey, M. M., Erbland, J., Picard, G., Preunkert, S., MacArthur, A., and Savarino, J.: Snow optical properties at Dome C (Concordia), Antarctica; implications for snow emissions and snow chemistry of reactive nitrogen, Atmos. Chem. Phys., 11, 9787-9801, doi:10.5194/acp-11-97872011, 2011.

France, J. L., Reay, H. J., King, M. D., Voisin, D., Jacobi, H. W., Domine, F., Beine, H., Anastasio, C., MacArthur, A., and LeeTaylor, J.: Hydroxyl radical and NOx production rates, black carbon concentrations and light-absorbing impurities in snow from field measurements of light penetration and nadir reflectivity of onshore and offshore coastal Alaskan snow, J. Geophys. Res., 117, D00R12, doi:101029/2011JD016639, 2012.

Galin, N., Worby, A., Markus, T., Leuschen, C., and Gogineni, P.: Validation of Airborne FMCW Radar Measurements of Snow Thickness Over Sea Ice in Antarctica, IEEE T. Geosci. Remote, 50, 3-12, 2012.

Gardner, A. and Sharp, M.: A review of snow and ice albedo and the development of a new physically based broadband albedo param- eterization, J. Geophys. Res., 115, doi:10.1029/2009JF001444, 2010.

Goldenson, N., Doherty, S. J., Bitz, C. M., Holland, M. M., Light, B., and Conley, A. J.: Arctic climate response to forcing from light-absorbing particles in snow and sea ice in CESM, Atmos. Chem. Phys., 12, 7903-7920, doi:10.5194/acp-12-7903-2012, 2012.

Grenfell, T., Light, B., and Sturm, M.: Spatial distribution and radiative effects of soot in the snow and sea ice during the SHEBA experiment: The surface heat budget of arctic ocen (SHEBA), J. Geophys. Res., 107, 8032, doi:10.1029/2000JC000414, 2002.

Grenfell, T. and Maykut, G.: The optical properties of ice and snow in the Arctic Basin, J. Glaciol., 18, 445-462, 1977.

Hansen, J. and Nazarenko, L.: Soot climate forcing via snow and ice albedos, P. Natl. Acad. Sci. USA, 101, 423-428, 2004.

Highwood, E. and Kinnersley, R.: When smoke gets in our eyes: The multiple impacts of atmospheric black carbon on climate, air quality and health, Environ. Int., 32, 560-566, 2006.

Holland, M. M., Bailey, D. A., Briegleb, B. P., Light, B., and Hunke, E.: Improved sea ice shortwave radiation physics in CCSM4: the impact of melt ponds and aerosols on Arctic sea ice, J. Climate, 25, 1413-1430, 2012.

Jacobson, M.: Strong radiative heating due to the mixing state of black carbon in atmospheric aerosols, Nature, 409, 695-697, 2001.

Jacobson, M.: Climate response of fossil fuel and biofuel soot, accounting for soot's feedback to snow and sea ice albedo and emissivity, J. Geophys. Res., 109, D21201, doi:10.1029/2004JD004948, 2004.

Kanagaratnam, P., Markus, T., Lytle, V., Heavey, B., Jansen, P., Prescott, G., and Gogineni, S. P.: Ultrawideband radar measurements of thickness of snow over sea ice, IEEE T. Geosci. Remote, 45, 2715-2724, 2007.

King, M. and Simpson, W.: Extinction of UV radiation in Arctic snow at Alert, Canada ( $\left.82^{\circ} \mathrm{N}\right)$, J. Geophys. Res., 106, 499-12, 2001.

King, M., France, J., Fisher, F., and Beine, H.: Measurement and modelling of UV radiation penetration and photolysis rates of nitrate and hydrogen peroxide in Antarctic sea ice: An estimate of the production rate of hydroxyl radicals in first-year sea ice, J. Photochem. Photobiol. A, 176, 39-49, 2005.

Kwok, R. and Cunningham, G. F.: ICESat over Arctic sea ice: Estimation of snow depth and ice thickness, J. Geophys. Res., 113, C08010, doi:10.1029/2008JC004753, 2008.

Kwok, R., Panzer, B., Leuschen, C., Pang, S., Markus, T., Holt, B., and Gogineni, S.: Airborne surveys of snow depth over Arctic sea ice, J. Geophys. Res., 116, C11018, doi:101029/2011JC007371, 2011.

Ledley, T. S. and Thompson, S. L.: Potential effect of nuclear war smokefall on sea ice, Climatic Change, 8, 155-171, 1986.

Lee-Taylor, J. and Madronich, S.: Calculation of actinic fluxes with a coupled atmosphere-snow radiative transfer model, J. Geophys. Res, 107, 4796, doi:10.1029/2002JD002084, 2002.

Light, B., Eicken, H., Maykut, G., and Grenfell, T.: The effect of included particulates on the spectral albedo of sea ice, J. Geophys. Res., 103, 27739-27752, 1998.

Light, B., Grenfell, T., and Perovich, D.: Transmission and absorption of solar radiation by Arctic sea ice during the melt season, J. Geophys. Res, 113, C03023, doi:10.1029/2006JC003977, 2008. 
Masiello, C.: Black carbon in deep-sea sediments, Science, 280, 1911-1913, 1998.

Massom, R., Eicken, H., Hass, C., and Jeffries, M.: Snow on Antarctic sea ice, Rev. Geophys., 39, 413-445, 2001.

Middelburg, J., Nieuwenhuize, J., and Breugel, P.: Black carbon in marine sediments, Mar. Chem., 65, 245-252, 1999.

Mitchell, M.: Visual range in the polar regions with particular reference to the Alaskan Arctic, J. Atmos. Terr. Phys., Spec. Suppl., 1957.

Perovich, D. K.: Complex yet translucent: the optical properties of sea ice, Physica B, 338, 107-114, 2003.

Perovich, D. K.: The interaction of ultraviolet light with Arctic sea ice during SHEBA, Ann. Glaciol., 44, 47-52, 2006.

Perovich, D. K.: Sea ice optics measurements, in: Field techniques for sea ice research, edited by: Eicken, H., Gradinger, R., Salganek, M., Shirasawa, K., Perovich, D., and Lepparanta, M., University of Alaska Press, 2009.

Perovich, D. K. and Polashenski, C.: Albedo evolution of seasonal Arctic sea ice, Geophys. Res. Lett., 39, L08501, doi:10.1029/2012GL051432, 2012.

Perovich, D. K., Roesler, C., and Pegau, W.: Variability in Arctic sea ice optical properties, J. Geophys. Res., 103, 1193-1208, 1998.

Perovich, D. K., Grenfell, T., Light, B., and Hobbs, P.: Seasonal evolution of the albedo of multiyear Arctic sea ice, J. Geophys. Res., 107, 8044, doi:10.1029/2000JC00438, 2002.

Phillips, G. and Simpson, W.: Verification of snowpack radiation transfer models using actinometry, J. Geophys. Res., 110, 8306, doi:10.1029/2004JD005552, 2005.

Ramanathan, V. and Carmichael, G.: Global and regional climate changes due to black carbon, Nat. Geosci., 1, 221-227, 2008.

Reay, H. J., France, J. L., and King, M. D.: Decreased albedo, $e$ folding depth and photolytic $\mathrm{OH}$ radical and $\mathrm{NO}_{2}$ production with increasing black carbon content in Arctic snow, J. Geophys. Res., 117, D00R20, doi:10.1029/2011JD016630, 2012.

Roessler, D. M. and Faxvog, F. R.: Optical properties of agglomerated acetylene smoke particles at $0.5145-\mu \mathrm{m}$ and $10.6-\mu \mathrm{m}$ wavelengths, J. Opt. Soc. Am., 70, 230-235, 1980.
Solomon, S., Qin, D., Manning, M., Chen, Z., Marquis, M., Averyt, K., Tignor, M., and Miller, H.: IPCC, 2007: Climate Change 2007: The Physical Science Basis. Contribution of Working Group I to the Fourth Assessment, Report of the Intergovernmental Panel on Climate Change, in: IPCC, 2007: Climate Change 2007: The Physical Science Basis. Contribution of Working Group I to the Fourth Assessment, Report of the Intergovernmental Panel on Climate Change, Cambridge University Press, 2007.

Stamnes, K., Tsay, S., Jayaweera, K., and Wiscombe, W.: Numerically stable algorithm for discrete-ordinate-method radiative transfer in multiple scattering and emitting layered media, Appl. Optics, 27, 2502-2509, 1988.

Suman, D., Kuhlbusch, T., and Lim, B.: Sediment Records of Biomass Burning and Global Change, Springer-Verlag, Berlin, 1997.

Warren, S.: Optical Properties of Snow, Rev. Geophys., 20, 67-89, 1982.

Warren, S. and Brandt, R.: Optical constants of ice from the ultraviolet to the microwave: A revised compilation, J. Geophys. Res, 113, D14220, doi:10.1029/2007JD009744, 2008.

Warren, S. G.: Impurities in snow: effects on albedo and snowmelt, Ann. Glaciol., 5, 177-179, 1984.

Warren, S. G. and Clarke, A.: Soot in the atmosphere and snow surface of Antarctica, J. Geophys. Res., 95, 1811-1816, 1990.

Warren, S. G. and Wiscombe, W.: A model for the spectral albedo of snow. II: Snow containing atmospheric aerosols, J. Atmos. Sci., 37, 2734-2745, 1980.

Warren, S. G. and Wiscombe, W.: Dirty snow after nuclear war, Nature, 313, 467-470, 1985.

Warren, S. G., Rigor, I., Untersteiner, N., Radionov, V., Bryazgin, N., Aleksandrov, Y., and Colony, R.: Snow depth on Arctic sea ice, J. Climate, 12, 1814-1829, 1999.

Weeks, W.: On Sea Ice, University of Alaska Press, 2010. 